\title{
Quantitation of T-lymphocyte Subsets Using the CELL-DYN Sapphire Automated Haematology
} Analyser

Jimyung Kim ${ }^{1}$, Seung $\mathrm{Ryu}^{2}$, Jinsook Lim', Gyechul Kwon $^{1}$, and Sunhoe Koo ${ }^{1}$

Departments of ${ }^{1}$ Laboratory Medicine and ${ }^{2}$ Emergency Medicine, Chungnam National University Hospital, Daejeon, Korea

Corresponding author: Jimyung Kim Department of Laboratory Medicine, Chungnam National University Hospital, 282 Moonhwa-ro, Joong-gu, Daejeon 301-721, Korea

Tel: $+82-42-280-7998$

Fax: $+82-42-257-5365$

E-mail: jmkim@cnuh.co.kr
Background: Quantitative analysis of T-lymphocyte subsets is used to assess immune competency. Traditionally, T-lymphocyte subset analysis has been performed using flow cytometry, which requires complex instrumentation and relatively skilled manual operation. We evaluated the performance of an automated haematology analyser, the CELL-DYN Sapphire (CD Sapphire; Abbott Laboratories, USA) for T-lymphocyte subset analysis.

Methods: The precision and linearity obtained using the CD Sapphire was evaluated. T-lymphocyte subsets in blood samples from 120 patients were quantified using CD Sapphire and flow cytometry (Cytomics FC 500; Beckman-Coulter, France). The time required for complete $\mathrm{T}$ cell subset analysis using both methods was also evaluated.

Results: Results of CD Sapphire-based quantitation of $\mathrm{CD}^{+}, \mathrm{CD}^{+} \mathrm{CD}^{+}$, and $\mathrm{CD}^{+} \mathrm{CD} 8^{+}$ cells showed intra-assay CV of less than $5 \%$ for precision and displayed linearity in the ranges of 84 to 5364,41 to 2615 , and 44 to 2800 cells/ $\mu \mathrm{L}$, respectively. There was good correlation among the $\mathrm{CD}^{+}, \mathrm{CD}^{+} \mathrm{CD}^{+}$, and $\mathrm{CD}^{+} \mathrm{CD}^{+}$cell counts as well as in the $\mathrm{CD} 4 / \mathrm{CD} 8$ ratio ( $r=0.987,0.982,0.982$, and 0.980 , respectively) using CD Sapphire and flow cytometry. The mean turnaround time for the CD Sapphire ( $10.0 \pm 0.5$ minutes) was significantly less than that for flow cytometry $(111.8 \pm 8.4$ minutes, $P<0.001)$.

Conclusions: $\mathrm{T}$ cell subset analysis using the $\mathrm{CD}$ Sapphire gives excellent performance and consistent results that correlate well with those obtained by flow cytometry. We conclude that this time-efficient method can replace conventional flow cytometric methods used for measuring $T$ cell subsets.

(J Lab Med Qual Assur 2014;36:39-47)

Key Words: CELL-DYN Sapphire, Flow cytometry, CD4-positive T-lymphocytes, CD8positive T-lymphocytes, T lymphocyte subsets

\section{INTRODUCTION}

T-lymphocytes participate in most adaptive immune responses and differentiated effector $\mathrm{T}$ cells are involved in the removal of pathogens. The estimation of T-lymphocyte subsets ( $\mathrm{CD} 4^{+}$and $\mathrm{CD}^{+} \mathrm{T}$ cells) can be used to assess immune competence, and this value is an important indicator used during the treatment of HIV infection, chemotherapy, and hematopoietic stem cell transplantation [1-3]. Traditional T-lymphocyte subset analysis is performed using flow cytometry, which requires relatively complex manual operations and additional white blood cell (WBC) measurements to calculate the absolute number of T-lymphocyte subsets. In addition, it is time-consuming, and takes approximately two hours for complete estimation. Furthermore, the differences in experience levels of operators may lead to variability in the analysis of results.

The CELL-DYN Sapphire automated haematology analyser (CD Sapphire; Abbott Laboratories, Abbott 


\title{
Journal of LABORATORY MEDICINE and QUALITY ASSURANCE
}

\author{
Jimyung Kim et al $•$ T-lymphocyte Subset Analysis Using CD Sapphire
}

Park, IL, USA) has a 488-nm blue diode laser and three fluorescent detectors to count WBCs and lymphocytes. These fluorescence measurements are also beneficial in the analysis of blood cell immunophenotypes. To calculate the counts of specific cell subsets, the automated analyser utilises both light scatter and fluorescence. The method of T-lymphocyte subset analysis has previously been developed and implemented with the Abbott CELLDYN 4000 analyser (CD4000; Abbott Laboratories). T-lymphocyte subset analysis using the CD4000 showed a good correlation with flow cytometric analysis [4-6]. However, there is no data on the performance characteristics of the CELL-DYN immunologic $\mathrm{T}$ cell determination reagents in the CD Sapphire, a more modern haematology analyser.

T cell subset analysis using the CD Sapphire is fully automated and takes 7 minutes per sample. The operator conducting the analysis is not exposed to the blood specimen and no special technical skills are required. Therefore, the use of this assay in routine analysis can ensure the timely reporting of results and laboratory safety while dealing with potentially biohazardous specimens, such as HIV. In this study, we aimed to evaluate the performance characteristics of the CD Sapphire in the measurement of T-lymphocyte subsets, and determine the efficacy of the CD Sapphire in the routine testing of samples.

\section{MATERIALS AND METHODS}

\section{Sample Collection}

Ethical approval to obtain blood samples from subjects was obtained from the institutional review board. The blood specimens from 120 patients (mean age, 41.8土 16.9 year; male:female $=86: 34)$ were collected using $\mathrm{K}_{3}$-EDTA-anticoagulant tubes. The subjects included 78 patients with HIV infection, 14 with malignancy (8 carcinoma, 5 myelodysplastic syndrome, 1 multiple myeloma), 17 with inflammation or infection, 9 with idiopathic thrombocytopenic purpura, and 2 with systemic lupus erythematosus. These specimens were stored at room temperature and analysed within eight hours of collection using the CD Sapphire and a Cytomics FC 500 flow cytometer (Beckman Coulter, Marseille, France). WBC and lymphocyte counts were measured using the CD Sapphire.

\section{Analysis of T-Lymphocyte Subsets Using Flow Cytometry}

The following monoclonal antibodies (mAbs) obtained from Beckman Coulter were used: CD3-fluoresceinisothiocyanate (FITC), CD4-phycoerythrin (PE), CD8PE. Whole blood (100 $\mu \mathrm{L})$ was stained with $20 \mu \mathrm{L}$ of CD3FITC mAbs/CD4-PE mAbs in one tube and $20 \mu \mathrm{L}$ of CD3FITC mAbs/CD8-PE mAbs in another tube. The mixture was incubated for 30 minutes at room temperature in the dark. Isotype-matched antibody controls were used to detect non-specific staining. The red blood cells were lysed using $0.5 \mathrm{~mL}$ OptiLyse solution (Beckman Coulter) and incubated for 15 minutes in the dark. The samples were analysed using a Cytomics FC 500 flow cytometer.

\section{CELL-DYN Immunologic T-Cell Analysis}

The CELL-DYN Immuno T-cell reagent kit (Abbott Laboratories) is supplied with lyophilized pellets of fluorochrome-tagged CD3/CD4 and CD3/CD8 monoclonal antibodies in two tubes. A stainless steel retainer holds the pellets at the bottom of each tube. The first CD3/ CD4 tube contains FITC-labelled CD3 and PE-labelled CD4 antibodies and the second CD3/CD8 tube contains FITC-labelled CD3 and PE-labelled CD8 antibodies. The T-lymphocyte subset measurements were performed automatically by placing a sample of EDTA whole blood next to a tube of CD3/CD4 reagent and a tube of CD3/CD8 reagent in the sample rack. After a period of mixing and incubation, the samples were analysed using the optical flow cell instrument software and the corresponding gating and scatter plots were generated as shown in Fig. 1.

\section{Evaluation Procedure}

The performance evaluation of the CD Sapphire was determined by the within-run imprecision, linearity, comparability, carryover, and turnaround time. The overall 
A
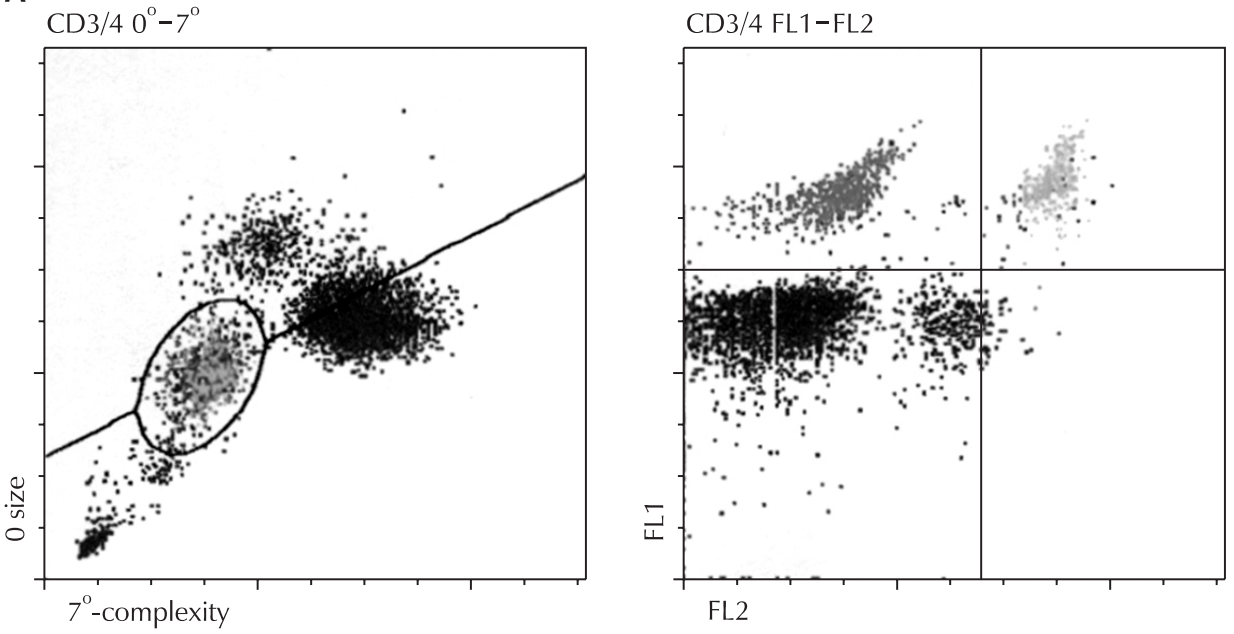

B

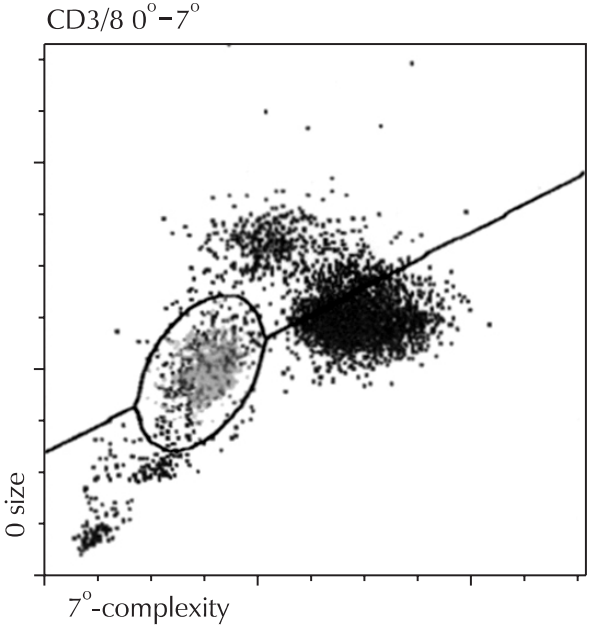

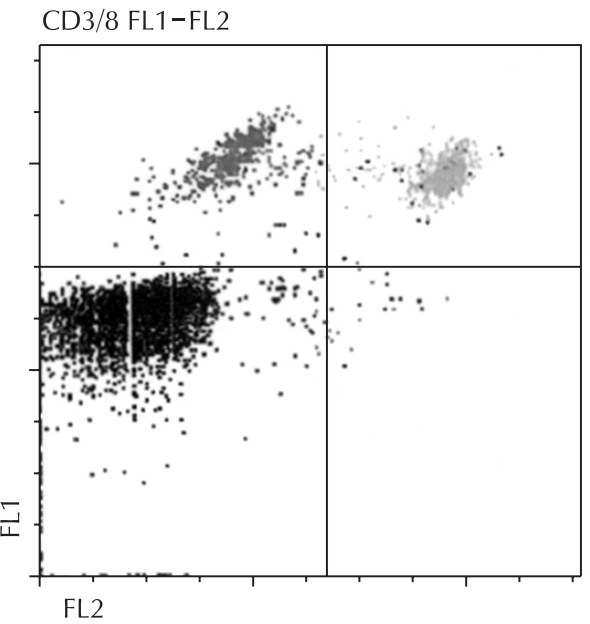

Fig. 1. Scatter plots generated by $\mathrm{T}$ cell subset analysis using the CELLDYN Sapphire analyser. $7^{\circ}$ scatter and $0^{\circ}$ scatter indicate cell granularity and cell size, respectively and the circled areas contains lymphocytes. The scatter plots shows CD4 or CD8 fluorescence (FL2) on the $\mathrm{x}$-axis and $\mathrm{CD} 3$ fluorescence (FL1) on the $y$-axis. (A) $\mathrm{CD}^{+}{ }^{+} \mathrm{CD} 4^{+}$and (B) $\mathrm{CD}_{3}^{+} \mathrm{CD} 8^{+}$ lymphocytes in the right upper quadrant are classified by combining light scatter and fluorescent scatter. precision within a run was evaluated by five consecutive measurements on 19 specimens with several counts of $\mathrm{CD}^{+}, \mathrm{CD}^{+} \mathrm{CD}^{+}$, and $\mathrm{CD} 3^{+} \mathrm{CD} 8^{+}$cells.

The linearity of the system was tested by measuring serial dilutions of a concentrated specimen. For this purpose, blood sample from a healthy donor was concentrated with a centrifugal method using Ficoll solution and the $\mathrm{CD}^{+}$ and $\mathrm{CD}^{+} \mathrm{CD}^{+}$counts were determined. Serial two-fold dilutions of the buffy coat plasma in the range of 1:1 to 1:64 were prepared. For $\mathrm{CD}^{+} \mathrm{CD} 8^{+}$counts, a blood specimen with a high percentage of $\mathrm{CD}^{+} \mathrm{CD}^{+}$cells was used. The $\mathrm{CD}^{+}, \mathrm{CD}^{+} \mathrm{CD}^{+}$, and $\mathrm{CD} 3^{+} \mathrm{CD}^{+}$cell counts were measured in duplicate for each dilution. The averages for each concentration were compared with ideal values and regression equations were calculated according to CLSI
EP6-A [7]. For the comparison study, $\mathrm{CD}^{+}, \mathrm{CD}^{+} \mathrm{CD} 4^{+}$, $\mathrm{CD}^{+} \mathrm{CD}^{+}$cell counts, and the $\mathrm{CD} 4 / \mathrm{CD} 8$ ratio obtained from the CD Sapphire were compared with those obtained from the FC 500 flow cytometer, in 120 specimens.

We assessed the carryover in the CD Sapphire T-cell assay using one blood sample with a high count (3,830/ $\mu \mathrm{L}, 1,960 / \mu \mathrm{L}$, and $1,580 / \mu \mathrm{L})$ of $\mathrm{CD}^{+}, \mathrm{CD}^{+} \mathrm{CD}^{+}$, and $\mathrm{CD}^{+} \mathrm{CD}^{+}$cells, respectively, and one blood sample with a low count $(733 / \mu \mathrm{L}, 146 / \mu \mathrm{L}$, and $585 / \mu \mathrm{L})$ of $\mathrm{CD}^{+}$, $\mathrm{CD}^{+} \mathrm{CD}^{+}$, and $\mathrm{CD}^{+} \mathrm{CD}^{+}$cells, respectively, based on the method of Broughton [8]. Each sample was consecutively tested three times and the percentage of carryover was calculated using the formula [(L1-L3)/(H3-L3) $\times 100$. The total time needed to complete the analysis on the CD Sapphire and the FC 500 flow cytometer was measured. 


\section{Journal of LABORATORY MEDICINE and QUALITY ASSURANCE}

\section{Jimyung Kim et al $•$ T-lymphocyte Subset Analysis Using CD Sapphire}

\section{Statistics}

All statistical analyses were performed using MedCalc statistical software ver. 11.3.0.0 (MedCalc Software, Mariakerke, Belgium). Continuous variables are presented as mean $\pm \mathrm{SD}$. Comparisons of the mean differences in the parameters between the CD Sapphire and FC 500 flow cytometer were performed using Student $t$-test. A linear regression model was used to check linearity. The correlation between the CD Sapphire and the FC 500 flow cytometer was evaluated using Spearman's rank correlation coefficient. A $P$-value less than 0.05 was considered significant.

Table 1. Within-run imprecision for specimens with several $\mathrm{CD}^{+}, \mathrm{CD}^{+} \mathrm{CD}^{+}$, and $\mathrm{CD}^{+}{ }^{+} \mathrm{CD} 8^{+} \mathrm{T}$ cell counts

\begin{tabular}{|c|c|c|}
\hline CELL-DYN Sapphire $(n=5)$ & Mean \pm SD & $\mathrm{CV}(\%)$ \\
\hline \multicolumn{3}{|l|}{$\mathrm{CD}^{+} \mathrm{T}$ cells $(/ \mu \mathrm{L})$} \\
\hline \multirow[t]{2}{*}{$<600$} & $548 \pm 20$ & 3.65 \\
\hline & $446 \pm 17$ & 3.81 \\
\hline \multirow[t]{2}{*}{$600-999$} & $738 \pm 10$ & 1.36 \\
\hline & $907 \pm 25$ & 2.76 \\
\hline \multirow[t]{3}{*}{$\geq 1,000$} & $1,244 \pm 26$ & 2.09 \\
\hline & $1,506 \pm 34$ & 2.26 \\
\hline & $3,086 \pm 68$ & 2.20 \\
\hline \multicolumn{3}{|l|}{$\mathrm{CD}^{+} \mathrm{CD}^{+} \mathrm{T}$ cells $(/ \mu \mathrm{L})$} \\
\hline \multirow[t]{2}{*}{$<400$} & $142 \pm 7$ & 4.93 \\
\hline & $310 \pm 15$ & 4.84 \\
\hline \multirow[t]{2}{*}{$400-799$} & $541 \pm 20$ & 3.70 \\
\hline & $758 \pm 29$ & 3.83 \\
\hline \multirow[t]{2}{*}{$\geq 800$} & $990 \pm 24$ & 2.42 \\
\hline & $1,434 \pm 42$ & 2.93 \\
\hline \multicolumn{3}{|l|}{$\mathrm{CD}^{+}{ }^{+} \mathrm{CD} 8^{+} \mathrm{T}$ cells $(/ \mu \mathrm{L})$} \\
\hline \multirow[t]{2}{*}{$<400$} & $289 \pm 12$ & 4.15 \\
\hline & $377 \pm 15$ & 3.98 \\
\hline \multirow[t]{2}{*}{$400-799$} & $598 \pm 15$ & 2.51 \\
\hline & $760 \pm 21$ & 2.76 \\
\hline \multirow[t]{2}{*}{$\geq 800$} & $1015 \pm 32$ & 3.15 \\
\hline & $2330 \pm 48$ & 2.06 \\
\hline
\end{tabular}

\section{RESULTS}

\section{Imprecision}

The within-run imprecision data of $\mathrm{CD} 3^{+}, \mathrm{CD}^{+} \mathrm{CD}^{+}$, and $\mathrm{CD}^{+} \mathrm{CD}^{+}$cell counts are shown in Table 1 . The results show an acceptable within-run imprecision. The CV obtained for all assays were below $5 \%$.

\section{Linearity}

The CELL-DYN Immuno T-cell assay showed excellent linearity in the evaluated ranges for $\mathrm{CD}^{+}, \mathrm{CD}^{+} \mathrm{CD}^{+}$, and $\mathrm{CD}^{+} \mathrm{CD}^{+}$cells (Fig. 2). The evaluated ranges for $\mathrm{CD}^{+}, \mathrm{CD}^{+} \mathrm{CD}^{+}$, and $\mathrm{CD}^{+} \mathrm{CD}^{+}$cells were 84 to 5,364 , 41 to 2,615 , and 44 to 2,800 cells $/ \mu \mathrm{L}$, respectively.

\section{Method Comparability}

The regression analysis data are summarized in Table 2. Overall correlation of the CD Sapphire with the flow cytometry method was good for the entire range of specimens. Although there were slight deviations, the slopes of the best fitting lines for all parameters (CD3 ${ }^{+}$ counts, $\mathrm{CD}^{+} \mathrm{CD}^{+}$counts, $\mathrm{CD} 3^{+} \mathrm{CD} 8^{+}$counts, and $\mathrm{CD} 4 /$ $\mathrm{CD} 8$ ratio) are close to unity, and the intercepts are small. The correlation coefficients $(r)$ were all $\geq 0.95$.

When specimens were classified into three subgroups on the basis of the $\mathrm{CD} 3^{+} \mathrm{CD} 4^{+}$cell counts by flow cytometry, the $\mathrm{CD}^{+} \mathrm{CD}^{+}$counts gave an $r$-value $\geq 0.95$ in 54 samples with $\mathrm{CD}^{+} \mathrm{CD}^{+}$counts of $500 / \mu \mathrm{L}$ or more, with the exception of 21 samples that had a $\mathrm{CD} 3^{+} \mathrm{CD} 4^{+}$ count of less than $200 / \mu \mathrm{L}(r=0.927)$, and 45 samples with a $\mathrm{CD}^{+} \mathrm{CD}^{+}$count of $200-499 / \mu \mathrm{L}(r=0.864)$. The correlation coefficients in specimens with $\mathrm{CD}^{+} \mathrm{CD} 4^{+}$cell counts less than $200 / \mu \mathrm{L}$ or in the range of $200-499 / \mu \mathrm{L}$ were lower than those in specimens with $\mathrm{CD} 3^{+} \mathrm{CD} 4^{+}$cell counts of $500 / \mu \mathrm{L}$ or more $(P=0.007, P<0.001)$, although there was a strong correlation among the subgroups.

When specimens were classified into two subgroups on the basis of the $\mathrm{CD} 4 / \mathrm{CD} 8$ ratio, the correlation coefficients of 78 samples with a low CD4/CD8 ratio of 1.0 or less, and in 42 samples with a CD4/CD8 ratio of more than 1.0, were more than 0.95 . There was no differences between the correlation coefficients of specimens with a CD4/CD8 
A

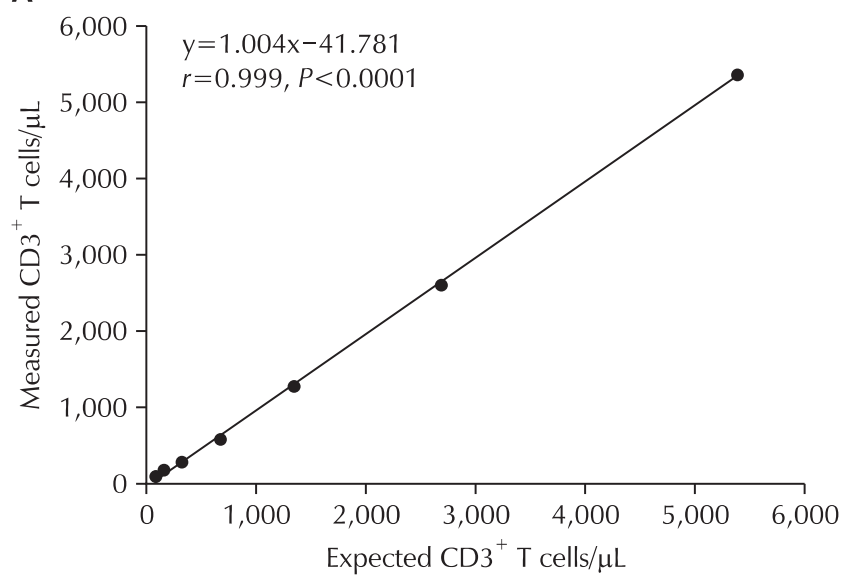

C

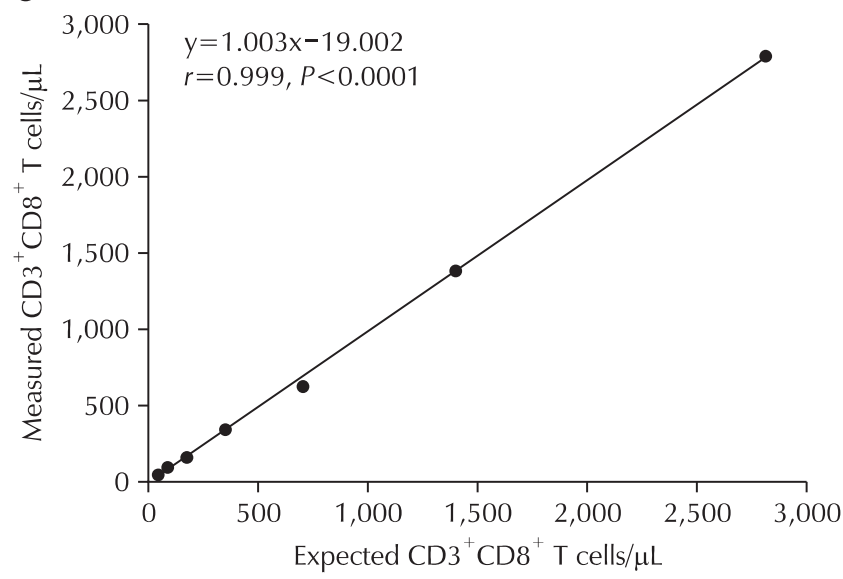

B

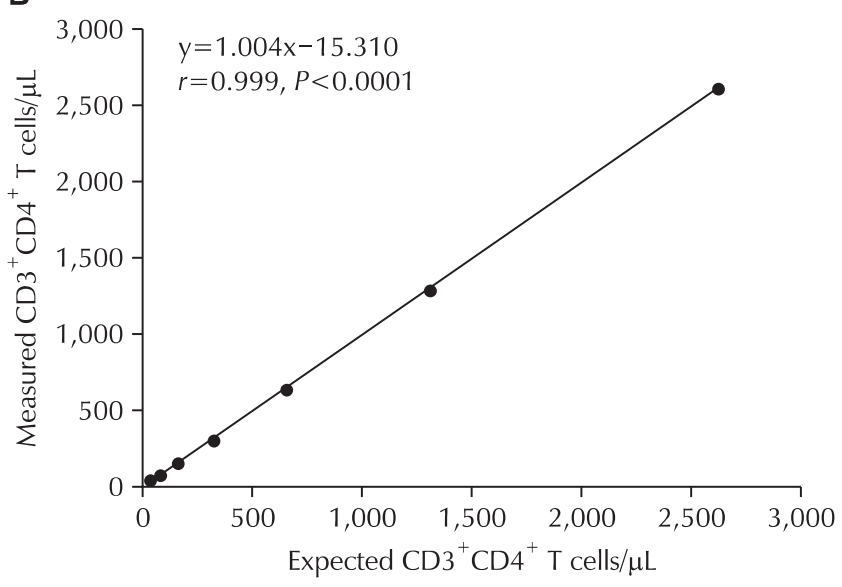

Fig. 2. Linearity for (A) $\mathrm{CD}^{+}$, (B) $\mathrm{CD}^{+} \mathrm{CD} 4^{+}$, and (C) $\mathrm{CD}^{+} \mathrm{CD}^{+} \mathrm{T}$ cell counts determined by the CELL-DYN Sapphire analyzer.

Table 2. Comparison of the CELL-DYN Sapphire with the Cytomics FC 500 in 120 blood specimens

\begin{tabular}{|c|c|c|c|c|}
\hline & Slope $(95 \% \mathrm{CI})$ & Intercept $(95 \% \mathrm{CI})$ & $r$ & $P$-value \\
\hline $\mathrm{CD}^{+} \mathrm{T}$ cells & $0.984(0.963$ to 1.006$)$ & $62.034(29.159$ to 94.909$)$ & 0.987 & $<0.001$ \\
\hline $\mathrm{CD}^{+}{ }^{+} \mathrm{CD} 4^{+} \mathrm{T}$ cells & $1.009(0.986$ to 1.032$)$ & $28.477(13.693$ to 43.260$)$ & 0.982 & $<0.001$ \\
\hline$<200 / \mu \mathrm{L}(\mathrm{n}=21)$ & $1.238(0.997$ to 1.478$)$ & $-3.453(-31.565$ to 24.658$)$ & 0.927 & $<0.001$ \\
\hline $200-499 / \mu \mathrm{L}(\mathrm{n}=45)$ & 1.057 ( 0.868 to 1.246$)$ & $14.981(-50.812$ to 80.773$)$ & 0.864 & $<0.001$ \\
\hline$\geq 500 / \mu \mathrm{L}(\mathrm{n}=54)$ & $0.993(0.959$ to 1.027$)$ & 42.159 (12.031 to 72.288$)$ & 0.983 & $<0.001$ \\
\hline $\mathrm{CD}^{+} \mathrm{CD}^{+} \mathrm{T}$ cells & $0.974(0.947$ to 1.001$)$ & 52.641 (29.036 to 76.247$)$ & 0.982 & $<0.001$ \\
\hline $\mathrm{CD} 4 / \mathrm{CD} 8$ ratio & 1.047 (1.012 to 1.082$)$ & $-0.033(-0.086$ to 0.020$)$ & 0.980 & $<0.001$ \\
\hline$\leq 1.0(\mathrm{n}=78)$ & $1.010(0.934$ to 1.086$)$ & $0.017(-0.024$ to 0.058$)$ & 0.950 & $<0.001$ \\
\hline$>1.00(\mathrm{n}=42)$ & $1.096(1.016$ to 1.175$)$ & $-0.185(-0.379$ to 0.010$)$ & 0.975 & $<0.001$ \\
\hline
\end{tabular}

Abbreviation: CI, confidence interval.

ratio of 1.0 or less, or with a CD4/CD8 ratio of more than $1.0(P=0.07)$.

\section{Carryover}

The percentages of high to low carryover for $\mathrm{CD} 3^{+}$, $\mathrm{CD}^{+} \mathrm{CD}^{+}$, and $\mathrm{CD}^{+} \mathrm{CD}^{+}$cell counts were $0.6 \%, 0.3 \%$, 


\title{
Journal of LABORATORY MEDICINE and QUALITY ASSURANCE
}

\author{
Jimyung Kim et al $•$ T-lymphocyte Subset Analysis Using CD Sapphire
}

and $0.3 \%$, respectively.

\section{Turnaround Time}

The hands-off time for testing using the CD Sapphire was 7 minutes and the hands-on time for test preparation was 3 minutes. The mean turnaround time for the CD Sapphire T cell analysis was $10.0 \pm 0.5$ minutes. Flow cytometric analysis took 20 minutes, which included preparation of samples and reagents, the warming of the flow cytometer, and the inputting of results. The mean turnaround time for flow cytometric analysis was 111.8 \pm 8.4 minutes. Thus, the $\mathrm{T}$ cell subset analysis using CD Sapphire has a significantly shorter turnaround time compared to conventional flow cytometric analysis $(P<0.001)$.

\section{DISCUSSION}

The CD Sapphire is a newer automated haematology analyser than the CD4000, but as with the CD4000, it uses flow cytometric principles in combination with impedance and optical technology to detect blood cell populations. These characteristics make these instruments useful for the analysis of various types of cells, the most representative application being the analysis of $\mathrm{T}$ cells using CD3, CD4, and CD8 monoclonal antibodies. Besides the CD4000, the more modern CD Sapphire has been recently introduced to estimate cells using flow cytometric principles and has been evaluated in the analysis of several surface antigens. Immunologic counting of platelets stained with anti-CD61 antibody using the CD Sapphire has been evaluated in several reports [9-11], and was proven superior to other automated methods [9]. A previous study explored the feasibility of implementing the use of several monoclonal antibodies besides CD61 in this haematology analyser [11]. Recently, a simple and rapid assay for lymphocyte subpopulations using antibodies for CD19, CD20, and CD16/56, in addition to CD3, CD4, and CD8 has also been developed [12].

In this study, the $\mathrm{CV}$ of $\mathrm{CD}^{+}, \mathrm{CD}^{+} \mathrm{CD}^{+}$, and $\mathrm{CD}^{+}$ $\mathrm{CD}^{+} \mathrm{T}$-lymphocytes at several count ranges have been determined to be less than $5 \%$ for within-run imprecision, indicating satisfactory reproducibility. In addition, the CD Sapphire demonstrated good linearity between 84 and 5,364 cells/ $\mu \mathrm{L}$ for $\mathrm{CD}^{+}$cell counts, 41 and 2,615 cells/ $\mu \mathrm{L}$ for $\mathrm{CD}^{+} \mathrm{CD}^{+}$cell counts, and 44 and 2,800 cells $/ \mu \mathrm{L}$ for $\mathrm{CD}^{+} \mathrm{CD}^{+}$cell counts.

Compared to flow cytometry measurements, the results of the $\mathrm{CD}^{+}, \mathrm{CD}^{+} \mathrm{CD}^{+}$, and $\mathrm{CD} 3^{+} \mathrm{CD} 8^{+} \mathrm{T}$-lymphocyte measurements using the CD Sapphire were slightly lower, but there were good correlations between the CD Sapphire and flow cytometry $(r=0.987,0.982$, and 0.982, respectively). A few previous reports $[7,9]$ of the CD4000 showed correlation coefficients of more than 0.90 , similar to this study. Although the correlation between the values of CD4/CD8 ratio was not evaluated in the previous studies, a good correlation was observed in the calculated CD4/CD8 ratio in our study.

Although the correlation coefficients $(r=0.927, r=0.864)$ were lower than those in specimens with $\mathrm{CD} 3^{+} \mathrm{CD} 4^{+}$cell counts of $500 / \mu \mathrm{L}$ or more $(r=0.983)$, there was a significant correlation in specimens with low $\mathrm{CD} 3^{+} \mathrm{CD} 4^{+}$cell counts (less than $200 / \mu \mathrm{L}$, or $200-499 / \mu \mathrm{L}$ ). This finding shows that the $\mathrm{CD} 3^{+} \mathrm{CD} 4^{+}$cell counts between the $\mathrm{CD}$ Sapphire and flow cytometry correlate well in the range of low $\mathrm{CD}^{+} \mathrm{CD}^{+}$cell counts, as well as in the range of $\mathrm{CD}^{+} \mathrm{CD}^{+}$cell counts of $500 / \mu \mathrm{L}$ or more. The correlation coefficient in the low $\mathrm{CD} 3^{+} \mathrm{CD} 4^{+}$cell count range is similar to that seen in previous studies $[5,6]$ using the CD4000. Yamane et al. [5] reported that there was strong correlation $(r=0.976)$ in $\mathrm{CD}^{+} \mathrm{CD}^{+}$cells counts (200/ $\mu \mathrm{L}$ or less) among 24 specimens and Hagihara et al. [6] showed that an excellent correlation $(r=0.88)$ was sustained in 30 CD4-reduced blood samples with counts in the range of 35 to 101 cells/ $\mu \mathrm{L}$. CD4/CD8 ratios had similar correlation coefficients in the low $\mathrm{CD} 4 / \mathrm{CD} 8$ ratio group $(r=0.950)$ and the normal CD4/CD8 ratio group $(r=0.975)$. We think that the correlation between the two methods is reliable even at low $\mathrm{CD} 3^{+} \mathrm{CD} 4^{+}$cell counts and a low $\mathrm{CD} 4 / \mathrm{CD} 8$ ratio.

The $\mathrm{CD}^{+} \mathrm{CD}^{+}$cell count has been used in the determination of immune status, monitoring of anti-HIV therapy, and the risk management of opportunistic infections $[1,13,14]$. Considering that the T-lymphocyte 


\title{
Journal of LABORATORY MEDICINE and QUALITY ASSURANCE
}

\author{
Jimyung Kim et al $•$ T-lymphocyte Subset Analysis Using CD Sapphire
}

subset analysis is mainly requested in outpatient care, quick and accurate reporting of results is needed for adequate diagnosis and treatment. Though conventional flow cytometry is a reference method, this procedure demands a special analyser, manual technical skills, and additional blood cell counting. Recently, point of care testing for $\mathrm{CD}^{+} \mathrm{CD}^{+} \mathrm{T}$ cells has been proposed as a reliable alternative [15], and there has been an increasing need for a simple and rapid $\mathrm{T}$ cell quantification method. In our study, the mean turnaround time for $\mathrm{T}$ cell subset analysis using the CD Sapphire was 10 minutes, significantly shorter than 111.8 minutes needed using flow cytometry. Most test results were reported within 15 minutes and any operator could conduct the measurements because no special skills are required for operating the CD Sapphire.

Since the CD Sapphire employs a closed and an automated blood sampling system, we performed a carryover assessment but no significant carryover was detected. This finding indicates that errors originating from reagents and samples are eliminated by using this measurement method.

Although sample stability could be a problem for $\mathrm{T}^{-}$ lymphocyte subset analysis [16], we did not assess sample stability in this experiment. In a previous study, scientists have reported that $\mathrm{CD} 3^{+} \mathrm{CD} 4^{+}$and $\mathrm{CD} 3^{+} \mathrm{CD} 8^{+}$counts are stable until 12 hours post-venipuncture and increase after 18 hours [11]. Although we did not examine the changes of $\mathrm{CD}^{+}, \mathrm{CD}^{+} \mathrm{CD}^{+}$, and $\mathrm{CD}^{+} \mathrm{CD}^{+}$counts in relation to the storage time, a sample stored for more than 12 hours showed a low white cell viability fraction and displayed an invalid data flag in our preliminary study. Hence, for our analysis, we only selected samples that were within 8 hours of collection. We presume that longer storage of samples could lead to inaccurate results in T-lymphocyte subset analysis using the CD Sapphire as well with flow cytometry.

CD Sapphire is a rapid and simple diagnostic platform that can be implemented for $\mathrm{T}$ cell subset analysis in all clinical laboratories, and generates precise results even at low T-lymphocyte counts compared to the conventional flow cytometry method. We conclude that this method can replace conventional flow cytometry for estimating $\mathrm{T}$ cell subsets and will help in ensuring efficiency with respect to time and labour in clinical laboratories.

\section{ACKNOWLEDGEMENTS}

We thank Abbott Korea Ltd. Diagnostics for donating Immuno T-cell (CD3/4/8) reagents.

\section{REFERENCES}

1. Vajpayee M, Kanswal S, Seth P, Wig N. Spectrum of opportunistic infections and profile of $\mathrm{CD} 4+$ counts among AIDS patients in North India. Infection 2003;31:336-40.

2. El-Chennawi FA, Al-Tonbary YA, Mossad YM, Ahmed MA. Immune reconstitution during maintenance therapy in children with acute lymphoblastic leukemia, relation to co-existing infection. Hematology 2008;13:203-9.

3. Giannelli R, Bulleri M, Menconi M, Casazza G, Focosi D, Bernasconi S, et al. Reconstitution rate of absolute $\mathrm{CD} 8^{+}$ T lymphocyte counts affects overall survival after pediatric allogeneic hematopoietic stem cell transplantation. J Pediatr Hematol Oncol 2012;34:29-34.

4. Marshall P, Hung D, Yuan J, Kim YR. Rapid, automated, close-tube quantitation of CD4+ and CD8+ T-cell populations on the Cell-Dyn 4000 hematology analyzer. Lab Hematol 2000;6:137-43.

5. Yamane T, Hagihara K, Nakamae H, Hasegawa T, Hino M. T-lymphocyte subset analysis using the automated hematology analyser CELL-DYN 4000 for patients with hematological disorders. Leuk Lymphoma 2006;47:503-6.

6. Hagihara K, Yamane T, Aoyama Y, Nakamae H, Hino M. Evaluation of an automated hematologyanalyzer (CELLDYN 4000) for counting CD4+ T helper cells at low concentrations. Ann Clin Lab Sci 2005;35:31-6.

7. Clinical and Laboratory Standards Institute. Evaluation of the linearity of quantitative measurement procedures: a statistical approach: approved guideline. Wayne (PA): Clinical and Laboratory Standards Institute, 2003.

8. Recommended scheme for the evaluation of instruments for automatic analysis in the clinical biochemistry laboratory. J Clin Pathol 1969;22:278-84. 


\section{Journal of LABORATORY MEDICINE and QUALITY ASSURANCE}

Jimyung Kim et al • T-lymphocyte Subset Analysis Using CD Sapphire

9. Grimaldi E, Del Vecchio L, Scopacasa F, Lo Pardo C, Capone F, Pariante S, et al. Evaluation of the platelet counting by Abbott CELL-DYN SAPPHIRE haematology analyser compared with flow cytometry. Int J Lab Hematol 2009;31:151-60.

10. Cid J, Nascimento JD, Vicent A, Aguinaco R, Escoda L, Ugarriza A, et al. Evaluation of low platelet counts by optical, impedance, and CD61-immunoplatelet methods: estimation of possible inappropriate platelet transfusion. Transfusion 2010;50:795-800.

11. Johannessen B, Roemer B, Flatmoen L, Just T, Aarsand AK, Scott CS. Implementation of monoclonal antibody fluorescence on the Abbott CELL-DYN Sapphire haematology analyser: evaluation of lymphoid, myeloid and platelet markers. Clin Lab Haematol 2006;28:84-96.

12. Molero T, Lemes A, DE LA Iglesia S, Scott CS. Monoclonal antibody fluorescence for routine lymphocyte subpopulation analysis with the Abbott CELL-DYN Sapphire haematology analyser. Int J Lab Hematol
2007;29:446-53.

13. Mildvan D, Bosch RJ, Kim RS, Spritzler J, Haas DW, Kuritzkes D, et al. Immunophenotypic markers and antiretroviral therapy (IMART): $\mathrm{T}$ cell activation and maturation help predict treatment response. J Infect Dis 2004;189:1811-20.

14. Nicholson JK. Use of flow cytometry in the evaluation and diagnosis of primary and secondary immunodeficiency diseases. Arch Pathol Lab Med 1989;113:598-605.

15. Briggs C, Machin S, Muller M, Haase W, Hofmann K, Forstreuter F, et al. Measurement of CD4+ T cells in point-of-care settings with the Sysmex pocH-100i haematological analyser. Int J Lab Hematol 2009;31:169-79.

16. Diagbouga S, Chazallon C, Kazatchkine MD, Van de Perre P, Inwoley A, M'Boup S, et al. Successful implementation of a low-cost method for enumerating CD4+ T lymphocytes in resource-limited settings: the ANRS 1226 study. AIDS 2003;17:2201-8. 
자동혈구분석기 CELL-DYN Sapphire를 이용한 T 림프구 아형의 정량분석

김지명 ${ }^{1}$ 유 승 $\bullet$ 임진숙 ${ }^{1}$ 권계철 ${ }^{1} \cdot$ 구선회 $^{1}$

충남대학교병원 ${ }^{1}$ 진단검사의학과, ${ }^{2}$ 응급의학과

배경: $T$ 림프구 아형(CD4 ${ }^{+}$and $\mathrm{CD}^{+} \mathrm{T}$ 세포)의 측정은 면역기능을 평가하는 데 사용되는데 기존 의 $\mathrm{T}$ 림프구 아형분석은 유세포분석기로 수행되어 왔다. 그러나 이 방법은 장비와 상대적으로 복잡 한 수작업을 필요로 한다. 본 연구는 자동혈구분석기 CELL-DYN Sapphire (CD Sapphire; Abbott Laboratories, USA)를 이용한 T 림프구 아형분석의 성능을 평가하고자 하였다.

방법: CD Sapphire의 정밀도와 직선성을 평가하였다. 120명의 환자 검체를 이용하여 CD Sapphire 로 측정한 각 $\mathrm{T}$ 림프구 아형의 정량값을 유세포분석기(Cytomics FC 500; Beckman-Coulter, France) 측정값과 비교하였으며 $T$ 림프구 아형분석의 소요시간을 측정하였다.

결과: 다른 $\mathrm{CD}^{+}, \mathrm{CD}^{+} \mathrm{CD}^{+}$및 $\mathrm{CD}^{+} \mathrm{CD}^{+}$세포수를 보이는 검체들에서 $\mathrm{CD}$ Sapphire의 검사 내 정밀도는 $5 \%$ 미만의 변동계수를 보였으며 $\mathrm{CD}^{+}, \mathrm{CD}^{+} \mathrm{CD} 4^{+}$및 $\mathrm{CD}^{+} \mathrm{CD}^{+}$세포수 $(/ \mu \mathrm{L})$ 는 각 각 84-5364, 41-2615, 및 44-2800의 범위에서 직선성을 나타내었다. 또한 $\mathrm{CD}^{+}, \mathrm{CD}^{+} \mathrm{CD} 4^{+}$, $\mathrm{CD}^{+} \mathrm{CD}^{+}$세포수 및 $\mathrm{CD} 4 / \mathrm{CD} 8$ 비의 CD Sapphire 측정값과 유세포분석기 측정값의 상관성은 우 수하였다 $(r=0.987,0.982,0.982,0.980) . C D$ Sapphire 측정법의 평균 소요시간은 10.0 \pm 0.5 분 으로 유세포분석법의 111.8 \pm 8.4 분에 비해 유의하게 짧았다 $(P<0.001)$.

결론: 자동혈액분석기 CD Sapphire를 이용한 T 림프구 아형분석은 적절한 성능과 유세포분석법과 의 우수한 상관성을 나타냈다. 따라서 이 방법은 $T$ 림프구 아형의 정량분석에 있어 기존의 유세포분 석법을 대치할 수 있으며 측정시간 단축에 유용할 것으로 생각한다.

(J Lab Med Qual Assur 2014;36:39-47)

\section{교신저자: 김지명}

우)301-721 대전시 중구 문화로 282, 충남대학교병원 진단검사의학과

Tel: 042)280-7998 Fax: 042)257-5365 E-mail: jmkim@cnuh.co.kr 